Zeszyty Naukowe Szkoły Głównej Gospodarstwa Wiejskiego w Warszawie

Problemy Rolnictwa Światowego tom 19 (XXXIV), zeszyt 3, 2019: 57-66 DOI: $10.22630 /$ PRS.2019.19.3.46

Jakub Kraciuk ${ }^{1}$

Szkoła Główna Gospodarstwa Wiejskiego w Warszawie

\title{
Wpływ międzynarodowych instytucji finansowych na sytuację gospodarczą krajów najsłabiej rozwiniętych
}

\section{Impact of International Financial Institutions on the Economic Situation of the Least Developed Countries}

\begin{abstract}
Synopsis. Celem opracowania było ukazanie wpływu działalności Międzynarodowego Funduszu Walutowego i Banku Światowego na sytuację ekonomiczną najsłabiej rozwiniętych krajów Afryki subsaharyjskiej. Stwierdzono, że działanie tych organizacji zgodnie $\mathrm{z}$ zasadami konsensusu waszyngtońskiego nie przyniosły oczekiwanych rezultatów, a pomoc kredytowa MFW i BŚ zwiększyła zadłużenie i nie przyczyniła się do wyraźnego wzrostu PKB per capita w analizowanych krajach. Dlatego też konieczna stała się zmiana reguł działania międzynarodowych instytucji finansowych wobec krajów najsłabiej rozwiniętych. Proponowane programy dostosowawcze mają generować wzrost gospodarczy, który będzie podporządkowany potrzebom społeczeństw, a wybór wariantów polityki ekonomiczno-społecznej powinien być dostosowany do warunków określonego kraju.
\end{abstract}

Słowa kluczowe: konsensus waszyngtoński, kraje najsłabiej rozwinięte, międzynarodowe instytucje finansowe

\begin{abstract}
The aim of the study was to show the impact of the activities of the International Monetary Fund and the World Bank on the economic situation of the least developed countries in sub-Saharan Africa. It was found that the operation of these organizations in accordance with the principles of the Washington consensus did not bring the expected results, and the credit aid of IMF and World Bank increased debt, but did not contribute to a significant GDP growth per capita in the analyzed countries. Therefore, it is necessary to change the rules of operation of international financial institutions towards least developed countries. The proposed adjustment programs are to generate economic growth, which will be subordinated to the needs of societies, and the choice of economic and social policy options should be adapted to the conditions of a given country.
\end{abstract}

Key words: the Washington consensus, least developed countries, international financial institutions

JEL Classification: F33, F34, F35, F63

Wstęp

Postępujące procesy globalizacji ekonomiczne mają znaczący wpływ na kształtowanie się zarówno gospodarki światowej jak też gospodarek poszczególnych krajów. Na sytuację ekonomiczną poszczególnych państw istotny wpływ mają najważniejsze podmioty procesu globalizacji, wśród których są międzynarodowe organizacje finansowe. Dzięki swojej aktywnej postawie, organizacje te stały się kluczowymi podmiotami globalnej ekonomii, wielokrotnie udowodniając swoją szczególną rolę w budowaniu jej obecnego kształtu. Przedmiotowa działalność tych organizacji jest najistotniejsza głównie tam, gdzie pomoc i

${ }^{1}$ dr hab. prof. SGGW, Katedra Ekonomii Międzynarodowej i Agrobiznesu SGGW, ul. Nowoursynowska 166, 02-787 Warszawa, e-mail: jakub_kraciuk@.sggw.pl; https://orcid.org/0000-0001-8046-147X 
wsparcie jest najpotrzebniejsze, a sytuacja taka ma miejsce właśnie w krajach najsłabiej rozwiniętych.

Zasadniczym celem opracowania było ukazanie oraz ocena wpływu działalności najważniejszych organizacji finansowych na sytuację gospodarczą krajów najsłabiej rozwiniętych. Praca miała także za zadanie odpowiedzieć na pytanie o przyszłe miejsce omawianych instytucji w globalnym organizmie polityczno-gospodarczym, oraz o charakter i formę oferowanej przez nie pomocy.

\section{Geneza i rozwój współczesnych międzynarodowych organizacji finansowych}

Już w latach trzydziestych XX w. pojawiła się idea utworzenia takiej organizacji, której nadrzędnym celem byłoby stabilizowanie kursów walutowych oraz uregulowanie zasad funkcjonowania międzynarodowego rynku walutowego. W trakcie II wojny światowej, zarówno w Wielkiej Brytanii (Plan Keynesa), jak i w Stanach Zjednoczonych (Plan White'a), prowadzone były prace nad potencjalnym statutem instytucji, mającej w przyszłości zmierzyć się z tymi wyzwaniami. Amerykański Departament Stanu w 1941 r. opracował memoriał dotyczący finansowych i monetarnych problemów w gospodarce światowej, zalecając jak najszybsze utworzenie funduszu o zasięgu międzynarodowym (Latoszek Proczek 2006). W lipcu 1944 roku w Bretton Woods w stanie New Hampshire w USA odbyła się konferencja z udziałem 44 państw (w tym Polski), podczas której podpisano status Międzynarodowego Funduszu Walutowego (MFW). Statut wszedł w życie 27 grudnia 1945 roku, po ratyfikowaniu go przez 29 państw uczestniczących w konferencji walutowej i dostarczających $80 \%$ kapitału zakładowego. Statut oparto na koncepcji White'a, w myśl której równowaga płatnicza krajów członkowskich ma być osiągana przez prowadzenie odpowiedniej polityki gospodarczej, do której zobowiązały się kraje uczestniczące w konferencji w Bretton Woods (Olszański 2004). W 1947 r. MFW podpisał oficjalnie umowę $\mathrm{z}$ ONZ, wchodząc $\mathrm{w}$ jej skład, jako organizacja wyspecjalizowana.

Do kluczowych zadań MFW należy między innymi: utrzymywanie płynności w międzynarodowych obrotach finansowych, działanie na rzecz stabilizacji rynków finansowych krajów członkowskich oraz pomoc kapitałowa w celu zrównoważenia bilansów płatniczych państw zrzeszonych (Łoś-Nowak 1998).

Ustalane przez Fundusz zasady dostępu do środków finansowych określane są jako warunkowość (ang. conditionality) i polegają na konieczności spełnienia przez państwo członkowskie określonych warunków w zamian za możliwość uzyskania finansowania ze strony MFW. Warunki te wpisane są w ramy programu dostosowawczego, który kraj członkowski zobowiązuje się realizować w zamian za udostępnienie pomocy finansowej. Program uzgodnionym z MFW jest kompleksowym planem reform gospodarczych, których realizacja ma na celu przywrócenie równowagi makroekonomicznej, w tym równowagi bilansu płatniczego, jak również zbudowanie trwałych podstaw stabilnego rozwoju gospodarczego (Gąsiorowski 2012).

Drugą $\mathrm{w}$ kolejności instytucją finansową o zasięgu globalnym, jest mający swoją siedzibę w Waszyngtonie Międzynarodowy Bank Odbudowy i Rozwoju (IBRD), nazywany również Bankiem Światowym (BŚ). Został on utworzony w lipcu 1944 r. w trakcie Monetarnej i Finansowej Konferencji Narodów Zjednoczonych w Bretton Woods. 
Początkowo liczył 41 członków, z łącznym kapitałem udziałowym wynoszącym 10 mld USD, chociaż pierwotnej ratyfikacji dokonało tylko 28 państw. Jest instytucją o charakterze komplementarnym do MFW, co oznacza miedzy innymi, że członkostwo w Funduszu automatycznie oznacza przyjęcie danego kraju jako sygnatariusza BŚ. Zasadniczym celem, dla którego został powołany Bank Światowy była pomoc krajom w odbudowie ze zniszczeń powstałych w wyniku II Wojny Światowej. W dalszych latach misja ta została znacznie poszerzona i obecnie określić ją należy, jako szerokie wsparcie rozwoju gospodarczego krajów członkowskich. Polega ona na udzielaniu preferencyjnych kredytów przeznaczonych na realizację precyzyjnie określonych programów i przedsięwzięć rozwojowych. Co istotne IBRD finansuje wyłącznie projekty, których autorami są rządy państw członkowskich lub też te, które zostały objęte oficjalną gwarancją rządową. Uwaga Banku Światowego skierowana jest obecnie głównie na kraje najuboższe, oraz gospodarkach krajów postkomunistycznych (Łoś-Nowak 1998).

Organizacją utworzoną w 1960 r. z inicjatywy ONZ, która wchodzi w skład tzw. Grupy Banku Światowego jest też Międzynarodowe Stowarzyszenie Rozwoju (IDA). Jej podstawowym zadaniem jest finansowe wspierania rozwoju gospodarczego najuboższych krajów świata, znajdujących się pod specjalnym patronatem ONZ, a określanych mianem najmniej rozwiniętych (least developed countries, LDC). Według stanu na marzec $2018 \mathrm{r}$. znajduje się na niej aktualnie 47 krajów afrykańskich, azjatyckich i rejonu Karaibów (List of Least Developed Countries 2018).

\section{Konsensus Waszyngtoński jako podstawa działania międzynarodowych instytucji finansowych}

W połowie lat 80. nastąpiło odejście od polityki keynesowskiej i uczyniono zwrot w kierunku lansowania w głównym nurcie ekonomii polityki prorozwojowej kształtowanej na założeniach teorii neoklasycznej. Podstawowe reguły tej polityki zostały skodyfikowane i nazwane przez J. Williamsona konsensusem waszyngtońskim (Williamson 1990). Zdaniem J. Williamsona, w latach 80 . XX w. wśród waszyngtońskich ekonomistów występowała zgodność w kwestii podstawowych elementów reform mających uzdrowić gospodarki krajów słabo rozwiniętych. J. Williamson wyróżnił dziesięć elementów a jego lista obejmowała takie punkty jak: dyscyplina finansowa, odpowiednie priorytety wydatków publicznych, reforma podatkowa, liberalizacja finansowa, jednolity kurs walutowy, liberalizacja handlu zagranicznego, stworzenie warunków dla napływu bezpośrednich inwestycji zagranicznych, prywatyzacja, deregulacja, prawa własności.

J. Williamson tworząc powyższą listę chciał uświadomić zmianę podejścia, jaka dokonała się w sposobie reformowania gospodarek krajów słabo rozwiniętych wśród ekonomistów zajmujących się tymi zagadnieniami, związanych z najbardziej wpływowymi na tym obszarze waszyngtońskimi instytucjami: Międzynarodowym Funduszem Walutowym i Bankiem Światowym. Podmioty z Bretton Woods stały się liderami zmian i reprezentantami idei neoliberalnej w świecie. J. Williamson jako rzecznik założeń promowanych przez wspomniane organizacje, stał się reprezentantem tych podmiotów w krajach słabo rozwiniętych (Gliniak 2016).

Analizując wytyczne ekonomistów z lat 90. dla krajów słabo rozwiniętych, można dojść do wniosku, że sprowadzały się one do praktycznie identycznych konkluzji. Według tych założeń, każdy kraj chcący zreformować swoją gospodarkę, tak aby dawała optymalne 
możliwości rozwoju wszystkim mieszkańcom, powinien trzymać się kilku proponowanych przez tych ekonomistów fundamentalnych zasad. Chodziło między innymi o dodatni bilans makroekonomiczny, wyeliminowanie ingerencji państwa w gospodarkę czy całkowite uwolnienie i uelastycznienie rynków. Hasła, takie jak stabilizacja, prywatyzacja i liberalizacja, stały się przewodnimi tezami dla ekonomistów technokratów, których zadaniem było opiniować czy ewaluować reformy, jakich mają dokonać państwa rozwijające się. $Z$ początku wspomniane zalecenia miały być wdrożone w Ameryce Południowej, jednak ze względu na szerokie możliwości wpływu stały się popularne na całym świecie (Gliniak 2016). Wspomniane hasła mieszczą się w ogólnych zasadach opracowanych w ramach konsensusu waszyngtońskiego. Przyjęto zasadę uniwersalności ograniczeń wzrostu gospodarczego, a zatem niezmienność w czasie i przestrzeni podstawowych reguł prowadzenia trafnej polityki prowzrostowej. Założono, że zmiany strukturalne w gospodarce, $\mathrm{w}$ tym $\mathrm{w}$ handlu zagranicznym, są automatycznym rezultatem stabilności makroekonomicznej oraz kształtowania przyjaznego otoczenia biznesowego (Soszyńska 2013).

\section{Działalność Banku Światowego i Międzynarodowego Funduszu Walutowego na rzecz krajów słabo rozwiniętych}

Z klasyfikacji Banku Światowego wynika, że wśród 40 najbiedniejszych państw świata za najsłabiej rozwinięte uznano aż 25 krajów Afryki subsaharyjskiej. Jest to skutek oddziaływania wielu czynników wewnętrznych i zewnętrznych. Spośród nich należy wymienić zwłaszcza (Kozanecka 2010):

1. Uwarunkowania historyczne, duży przyrost naturalny, rozpowszechniony analfabetyzm, przewagę ludności utrzymującej się z rolnictwa, niedorozwój przemysłu przetwórczego (z wyłączeniem RPA), przy dużym potencjale surowców mineralnych oraz rolniczych.

2. Słabość struktur instytucji państwowych, ciagłe konflikty zbrojne, które niszczą istniejący ludzki dorobek, powodując równocześnie masowe ucieczki ludności $\mathrm{z}$ dotychczasowych miejsc zamieszkania.

3. Niskie stopy oszczędności wewnętrznych, a tym samym niedobór kapitału na rozwój gospodarczy i opanowanie ubóstwa.

Podobnie jak wiele innych krajów mających problemy z bilansem płatniczym czy też zadłużeniem zagranicznym, także państwa regionu subsaharyjskiego poddane zostały w ostatnim ćwierćwieczu oddziaływaniu nowej polityki ekonomicznej w postaci tzw. konsensusu waszyngtońskiego (Bożyk 2008). Jego główną ideą było prowadzenie takiej polityki, która zapewniałaby przechodzenie od stagnacji do wzrostu $\mathrm{w}$ zaburzonych gospodarkach rynkowych, a warunkiem tego miało być przyjęcie modelu gospodarki liberalno-monetarnej. Aby wprowadzić te założenia w życie, wypracowano na przełomie lat 80. i 90. ubiegłego wieku porozumienie pomiędzy Międzynarodowym Funduszem Walutowym, Bankiem Światowym i Departamentem Skarbu Stanów Zjednoczonych, będące zbiorem zasad mających najlepiej służyć rozwojowi gospodarczemu (Stiglitz 2007).

Pomoc krajom najsłabiej rozwiniętym świadczona była głównie przez dwie wyspecjalizowane agencje Banku Światowego: Międzynarodowy Bank Odbudowy i Rozwoju (IBRD) oraz Międzynarodowe Stowarzyszenie Rozwoju (IDA). Od momentu powstania Grupa Banku Światowego pracowała nad tym, aby pomóc ponad 100 krajom 
rozwijającym się dostosować się do tych zmian, oferując pożyczki, wspierając fachową wiedzą i usługami konsultacyjnymi. Grupa Banku Światowego współpracuje aktywnie z rządami krajowymi, sektorem prywatnym, organizacjami społeczeństwa obywatelskiego, regionalnymi bankami rozwoju, ośrodkami analitycznymi i innymi instytucjami międzynarodowymi, w zakresie minimalizacji negatywnych skutków zmian klimatycznych, rozwiązywania konfliktów, bezpieczeństwa żywnościowego, edukacji, rolnictwa, finansów $\mathrm{i}$ handlu. Wszystkie te wysiłki wspierają bliźniacze cele Grupy Bankowej związane z likwidacją skrajnego ubóstwa do 2030 r. i poprawą sytuacji najbiedniejszych krajów. Wraz z rosnącym zapotrzebowaniem na jej usługi, Grupa Banku Światowego zmuszona była wciąż się rozwijać. $Z$ perspektywy czasu jest to szczególnie zauważalne analizując wielkość udzielonych przez Bank Światowy pożyczek. Na początku swojej działalności w 1947 roku udzielił on zaledwie czterech pożyczek o łącznej wysokości 497 mln USD, aby tylko w 2015 roku podpisać i przekazać swoim członkom sumę blisko 60 mld USD w formie 302 skonkretyzowanych projektów docelowych. Analizując dane historyczne widać jak ogromny wkład finansowy został dotychczas przeznaczony na realizację celów statutowych Banku Światowego w obszarze dotyczącym najbiedniejszych krajów naszego globu. W przeciagu prawie 58-letniej historii istnienia agencji IDA przygotowała na potrzeby swoich klientów 6169 różnych projektów, na łączną kwotę 359 mld USD, z tego dla najbiedniejszych krajów Afryki subsaharyjskiej przekazała pomoc w kwocie 165 mld (The World Bank...).

Tabela 1. Wartość pomocy finansowej Banku Światowego i Międzynarodowego Funduszu Walutowego dla wybranych krajów afrykańskich (w mln USD)

Table 1. Value of financial aid from the World Bank and the International Monetary Fund for selected African countries (in USD million)

\begin{tabular}{|c|c|c|c|c|c|c|c|c|}
\hline \multirow{2}{*}{$\begin{array}{c}\text { Kredyty, } \\
\text { pożyczki } \\
\text { i granty } \\
\text { (mln } \\
\text { USD) }\end{array}$} & \multicolumn{2}{|c|}{ MFW } & \multicolumn{2}{|c|}{ IBRD } & \multicolumn{2}{|c|}{ IDA } & \multirow{2}{*}{$\begin{array}{c}\text { Łączna } \\
\text { wartość } \\
\text { przyznanej } \\
\text { pomocy }\end{array}$} & \multirow{2}{*}{$\begin{array}{c}\text { Łączna } \\
\text { wartość } \\
\text { wykorzystanej } \\
\text { pomocy }\end{array}$} \\
\hline & $\begin{array}{c}\text { Przyznana } \\
\text { kwota }\end{array}$ & $\begin{array}{l}\text { Kwota } \\
\text { pobrana }\end{array}$ & $\begin{array}{l}\text { Przyznana } \\
\text { kwota }\end{array}$ & $\begin{array}{c}\text { Kwota } \\
\text { pobrana }\end{array}$ & $\begin{array}{c}\text { Przyznana } \\
\text { kwota }\end{array}$ & $\begin{array}{c}\text { Kwota } \\
\text { pobrana }\end{array}$ & & \\
\hline Nigeria & 3158 & - & 7143 & 5439 & 15439 & 9338 & 25740 & 14776 \\
\hline Etiopia & 650 & 566 & 109 & 109 & 20307 & 13711 & 21065 & 14386 \\
\hline Tanzania & 1718 & 1217 & 361 & 356 & 14014 & 10905 & 16094 & 12477 \\
\hline Ghana & 4277 & 3417 & 390 & 190 & 10397 & 8568 & 15065 & 12175 \\
\hline Kenia & 5490 & 2143 & 1236 & 984 & 12546 & 6999 & 19272 & 10126 \\
\hline
\end{tabular}

Źródło: opracowanie własne na podstawie History of Lending Arrangements as of April 30, 2018. Pobrano 2 czerwca z: http://www.imf.org/external/np/fin/tad/extarr2.aspx? memberkey $1=65 \&$ date1Key=2018-04-30, World Bank Group Finances, https://financesapp.worldbank.org/en/countries/.

Do statutowych zadań Międzynarodowego Funduszu Walutowego obok roli regulacyjnej polegającej na nadzorowaniu przestrzegania przez państwa członkowskie reguł kursowych oraz stosowania ograniczeń walutowych, roli konsultacyjnej sprowadzającej się do usług techniczno-doradczej, należy funkcja kredytowa, polegająca na dostarczaniu krajom członkowskim środków finansowych w przypadku pojawienia się $\mathrm{w}$ tych krajach problemów związanych z bilansem płatniczym. W przypadku krajów, które w wyniku utraty wiarygodności kredytowej utraciły jednocześnie dostęp do międzynarodowych rynków finansowych, kredyt udzielony przez Międzynarodowy 
Fundusz Walutowy jest właściwie jedynym dostępnym dla nich źródłem finansowania w czasie wdrażania trudnych reform gospodarczych (Gąsiorowski 2012). Dla krajów najsłabiej rozwiniętych Międzynarodowy Fundusz Walutowy oferuje porozumienia na warunkach preferencyjnych, a najważniejszym $\mathrm{z}$ nich jest fundusz na rzecz Redukcji Ubóstwa i Wzrostu Zaufania (Poverty Reduction and Growth Trust, PRGT), będący jednocześnie największym funduszem powierniczym w MFW (Gąsiorowski 2012).

Oceny wpływu pomocy zewnętrznej na sytuację ekonomiczną najsłabiej rozwiniętych krajów Afryki dokonano biorąc pod uwagę największych dłużników międzynarodowych instytucji kapitałowych z tej grupy państw. Należą do nich Nigeria, Etiopia, Tanzania, Ghana i Kenia. Największym beneficjentem pomocy z ramienia IDA jest Etiopia, która w formie kredytów, pożyczek i grantów faktycznie otrzymała do tej pory 13,7 mld USD. Uwzględniając natomiast pomoc oferowaną przez MFW oraz IBRD, pierwsze miejsce w wysokości zaciagnniętych zobowiązań zajmuje Nigeria (tab. 1). Na uwagę zasługuje fakt, że Nigeria jako jedyna $\mathrm{z}$ badanej grupy nigdy nie skorzystała $\mathrm{z}$ żadnego $\mathrm{z}$ kierowanych do niej instrumentów stabilizacji bilansu płatniczego, traktując je wyłącznie jako narzędzie ostrożnościowe. Kraj ten był również największym odbiorcą pomocy strukturalnej z IBRD (5,4 mld USD), która stanowiła 76,9\% wszystkich desygnowanych na ten cel środków.

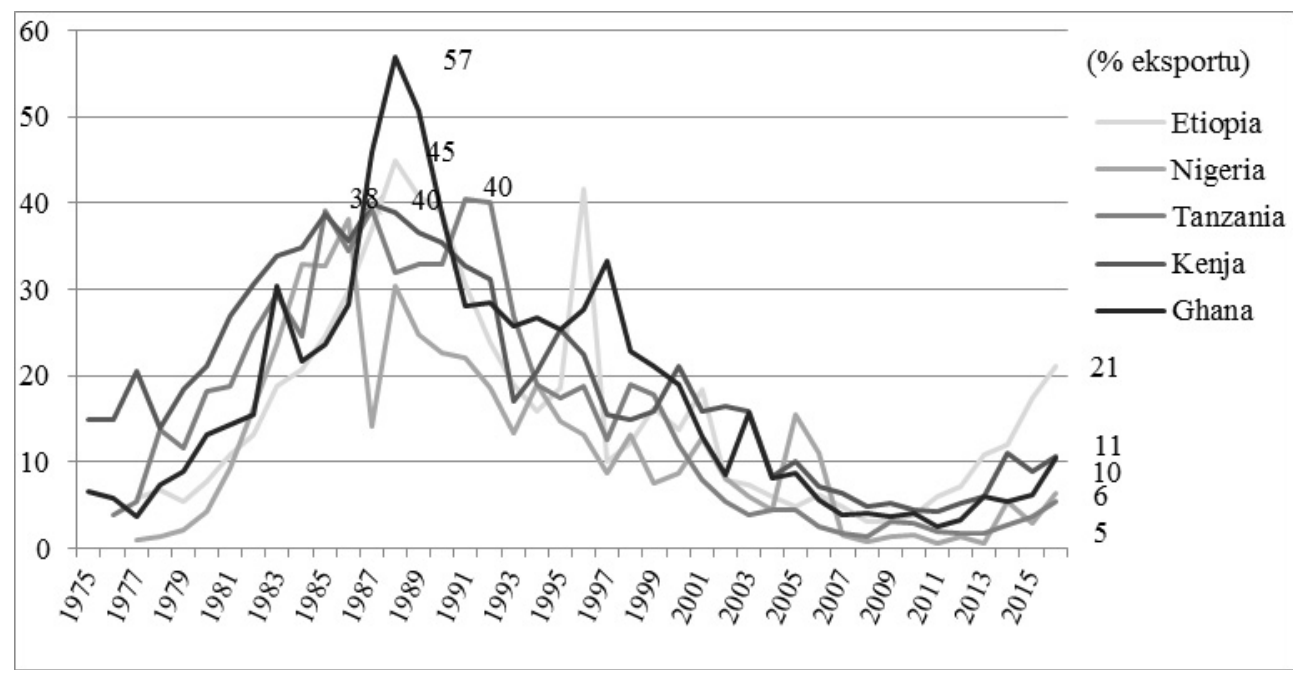

Rys. 1. Wskaźnik wysokości obsługi zadłużenia zagranicznego w stosunku do wartości eksportu w wybranych krajach afrykańskich

Fig. 1. Indicator of foreign debt servicing in relation to the value of exports in selected African countries

Źródło: opracowanie własne na podstawie The World Bank. Data. Pobrano 2 czerwca z: https://data.worldbank. org/country.

Zaciągane przez analizowane kraje kredyty zostały w różnym stopniu wykorzystane. Do określenia kondycji systemu finansowego krajów zaciagających kredyty wykorzystuje najczęściej wskaźnik wysokości obsługi zadłużenia zagranicznego w stosunku do wartości eksportu. Wysoka wartość badanego wskaźnika wskazuje na ryzyko utraty możliwości spłaty długów i poważnego zaburzenia płynności finansowej (Kaczmarczyk Mika 2004). 
Pod koniec lat 70. zarówno wysokość zadłużenia jak i koszty związane z jego obsługą były relatywnie niskie, czego przykładem jest Nigeria, która na ten cel przeznaczyła w 1977 r. zaledwie 1\% swojego łącznego wpływu z eksportu.

W analogicznym okresie w Kenii wskaźnik był aż 20-krotnie wyższy. Kolejne 10 lat to wyraźny i skokowy wzrost analizowanego parametru. Krytyczny moment to rok 1988, w którym Ghana przeznaczała na obsługę zadłużenia aż 57\% środków pozyskiwanych z tytułu zagregowanego eksportu. Bez żadnej przesady można stwierdzić, że było to obciazzenie o dramatycznych skutkach dla kondycji ekonomicznej państwa. Był to bezpośredni efekt niekontrolowanego zaciagania pożyczek z MFW, z którego w przeciagu zaledwie 10 lat kraj ten dokonał ciagnienia na blisko 1,5 mld USD. Rok 1988 był krytyczny również dla Etiopii, (wartość wskaźnika 45\%) lecz w tym przypadku głównym tego powodem była konieczność spłaty rat z tytułu pożyczek IDA. W kolejny latach wyraźnie zauważalny jest trend spadkowy badanego wskaźnika. Wartym odnotowanie jest fakt, że w 2013 r. Nigeria nie poniosła żadnych kosztów obsługi zadłużenia a badany parametr wyniósł 0. W 2015 roku wartości wskaźników są już zdecydowanie wyższe, a w przypadku Etiopii wskaźnik ten przekraczał $20 \%$.

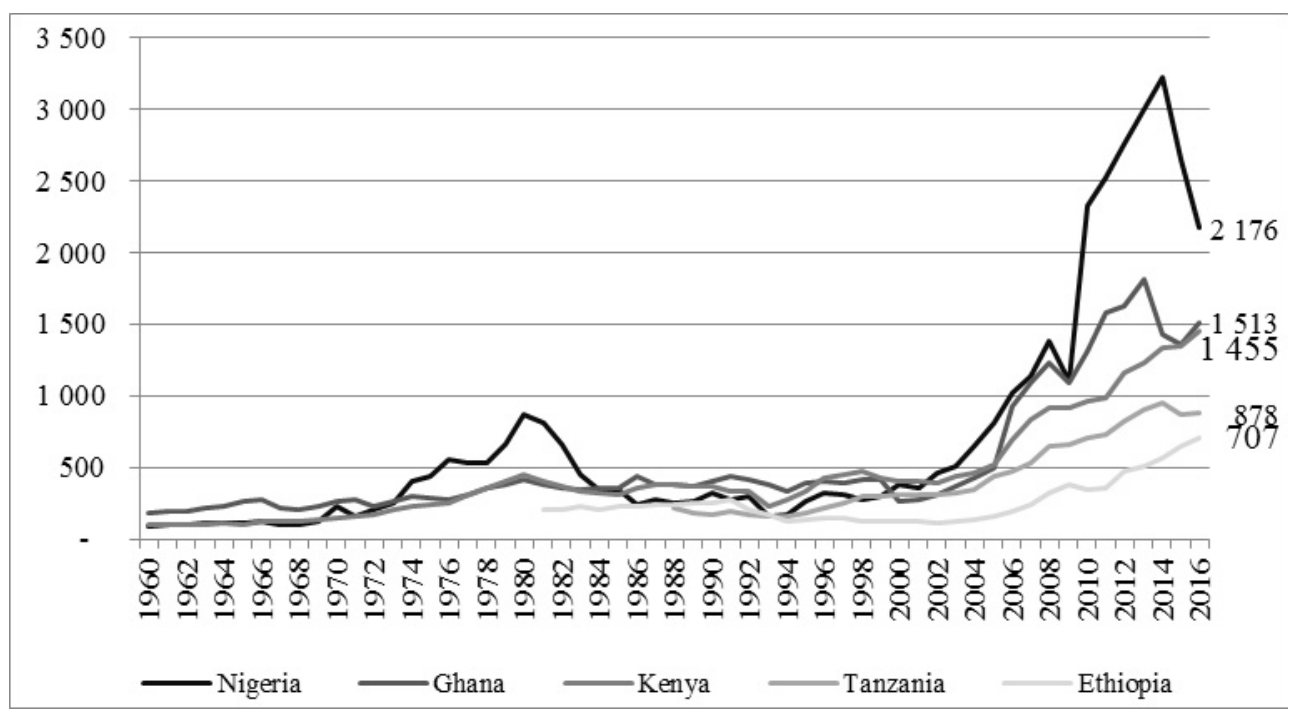

Rys. 2. Zmiany wartości PKB per capita w USD w wybranych krajach afrykańskich

Fig. 2. Changes in GDP per capita in USD in selected African countries

Źródło: opracowanie własne na podstawie The World Bank. Data Pobrano 2 czerwca z: https://data.worldbank.org/country.

Pomimo zakrojonych na szeroką skalę programów pomocowych w przeciągu 43 lat (od 1960 do 2002 roku) wysokość PKB per capita zwiększyła się zaledwie o $254 \%$, a gdyby nie wyraźnie odstająca na tle grupy Nigeria parametr ten byłby jeszcze niższy. Na tle reszty świata to wynik wręcz katastrofalny, $\mathrm{w}$ pełni pokazujący skalę problemów analizowanych krajów najsłabiej rozwiniętych. Według kryteriów ustalonych przez Bank Światowy, a dotyczących wysokości PKB per capita, w 2016 roku Etiopia nadal należała do grona krajów o najniższym dochodzie $(<875$ USD). Dodatkowo $\mathrm{z}$ uwagi na wysokie zadłużenia zagraniczne, umieszczano ją w grupie państw poważnie zadłużonych o niskim 
dochodzie (Kaczmarczyk, Mika 2004). Nieznacznie powyżej progu 875 USD znajdowała się Tanzania (878 USD). Pozostałe kraje teoretycznie plasują się $\mathrm{w}$ grupie krajów o średnim dochodzie (między 875 a 10275 USD) lecz jest to tak szeroka skala, a wartości analizowanego wskaźnika oscylują zdecydowanie w jego dolnych granicach, za wyjątkiem Nigerii, która z uwagi na mocno rozwinięty przemysł wydobywczy i przetwórczy ropy naftowej, obok RPA stopniowo wyrasta na lidera regionu Afryki subsaharyjskiej. Reasumując można stwierdzić, że zarówno programy strukturalne IBRD, wsparcie finansowe IDA jak i instrumenty używane przez MFW, nie spowodowały znacznego podniesienia wartości wskaźnika PKB per capita. Oczywiście na wysokość tego wskaźnika miał wpływ szereg innych czynników ekonomiczno-politycznych, jednak w oparciu o przedstawione dane można stwierdzić, że w rozpatrywanych przypadkach nie zauważono bezpośredniego i kluczowego wpływu zaciąganych kredytów i otrzymywanych grantów na poprawę sytuacji gospodarczej analizowanych krajów. Nasuwa się zatem pytanie, dlaczego w krajach słabo i średnio rozwiniętych, w których konsekwentnie wdrażano reguły konsensusu waszyngtońskiego, osiągano na ogół mierne wyniki gospodarcze. Według J. Stiglitza (2004) zasady konsensusu traktowano w sposób technicystyczny oraz zakładano, że $\mathrm{w}$ im wyższym stopniu będą one zrealizowane, tym lepiej. Przykładem tego może być stwierdzenie J. Williamsona (2000), że proponowana liberalizacja przepływu międzynarodowego kapitału finansowego była na ogół wdrażana w szerszym zakresie niż pierwotnie przewidywano. Drugim mankamentem było bezwzględne stosowanie przez najuboższe kraje zasad postępowania neoliberalnego, czyli nie uwzględniania faktu, że mechanizmy rynkowe w pewnych sytuacjach są zawodne, dalekie od obrazu modelowego. Niedocenienie znaczenia konkurencji w konsensusie waszyngtońskim jest także jednym z głównych jego mankamentów. Inną tego typu wadą było pominięcie konieczności stworzenia efektywnej infrastruktury prawno-instytucjonalnej. Aby rynek mógł prawidłowo funkcjonować musi istnieć odpowiednia infrastruktura instytucjonalno-prawna, system powinien być transparentny i muszą być zagwarantowane prawa własności. Nie można także pomijać konieczności istnienia sprawnych instytucji finansowych. Nowoczesna teoria makroekonomii zwraca szczególną uwagę na powiązania między rynkami finansowymi a sferą realną gospodarki. Pokazuje na kluczowe znaczenie rynków finansowych dla fluktuacji gospodarczych i wzrostu gospodarczego. Sukces rozwoju nie polega jedynie na zmniejszaniu luki w zakresie kapitału fizycznego, ale i w zakresie wiedzy. Ważna jest nie tylko wiedza o procesach produkcyjnych, ale istotne znaczenie ma także wiedza o właściwym funkcjonowaniu instytucji, czy też z zakresu organizacji i zarządzania (Piasecki 2008).

Na przełomie lat 80 . i 90 . nadzieje na oczekiwane osiagnięcia gospodarcze zostały zawiedzione, zwłaszcza gdy zestawiano je z sukcesami wybranych krajów stosujących inne strategie rozwoju gospodarczego np. Krajów Azji Południowo-Wschodniej. Praktycznie na przełomie XX i XXI wieku skrystalizowały się cztery podejścia do reguł prorozwojowych konsensusu waszyngtońskiego:

- zwolennicy pierwszego z nich, najczęściej skupieni wokół Międzynarodowego Funduszu Walutowego uważają, że jeśli skutki gospodarcze z tytułu wdrażania reform z listy konsensusu waszyngtońskiego są nieoczekiwanie skromne, to znaczy, że za mało postępu dokonano we wdrażaniu tych reform i należy je wdrożyć w wyższym stopniu,

- część tego środowiska uznała, że pierwotna lista warunków trafnego prowzrostowego modernizowania gospodarki nie była wystarczająco kompletna, w sensie wskazania warunków koniecznych i dostatecznych prowadzenia zdrowej strategii 
prowzrostowej, a zatem zaproponowała poszerzenie tej listy. $\mathrm{W}$ ten sposób nowa uzupełniona lista $\mathrm{w}$ literaturze przedmiotu nazwana została powiększonym konsensusem waszyngtońskim lub konsensusem waszyngtońskim plus (Stiglitz 2004).

- pewna wąska grupa badaczy i decydentów zaczęła poszukiwać całkowicie nowego ładu gospodarczego, nowej teorii ekonomicznej i wynikających z niej reguł postępowania prowzrostowej modernizacji gospodarki. O ile zwarta, całościowa teoria, według której stworzono by podstawy nowego paradygmatu, który pozwalałby w sposób bardziej zgodny z realiami gospodarczymi opisać przejrzyście podstawowe procesy w sferze gospodarowania jak na razie nie powstała, to w pewnych wąskich kręgach lansowane są wzorce takich reguł, jak przykładowo konsensus pekiński (Soszyńska 2013).

- autorzy czwartego podejścia są zwolennikami braku możliwości sformułowania uniwersalnych reguł prowzrostowego modernizowania gospodarki.

Powiększony konsensus waszyngtoński niezależnie od jego wariantu uzupełniony został o zalecenia reform drugiej generacji, z których większość dotyczyła instytucji jako reguł gry.

\section{Podsumowanie}

Podsumowując, można stwierdzić, że polityka międzynarodowych organizacji finansowych nie prowadziła do rozwiązania narastających $\mathrm{w}$ omawianym regionie problemów. Kraje Afryki subsaharyjskiej nadal tworzą najbiedniejszy region na naszym globie. Dystans dzielący go od reszty świata, mierzony np. wartością PKB na jednego mieszkańca, jest ogromny, a w okresie realizacji programu strukturalnego dostosowania jeszcze się pogłębił. Nadal ograniczony jest udział tego regionu w wymianie międzynarodowej. Wydaje się, że ważnymi problemami są usprawnienie działalności struktur państwowych, ożywienie funkcji państwa i władz lokalnych w sferze społecznej, wyważone wzmocnienie roli państwa, w kształtowaniu i prowadzeniu polityki gospodarczej Widać dziś, że narzucony omawianym krajom model gospodarki mieszczący się w kanonach konsensusu waszyngtońskiego się nie sprawdził i należy go skorygować. Wzrost gospodarczy powinien być podporządkowany potrzebom społeczeństw, a wybór wariantów polityki ekonomiczno-społecznej powinien być dostosowany do warunków określonego kraju. Takie rozumowanie nie stoi w sprzeczności z istotą globalizacji, jednak kwestionuje dotychczasową politykę takich instytucji międzynarodowych, które odeszły od idei rozwoju zrównoważonego, preferując wybitnie sektor bankowy kosztem sektora produkcyjnego (Kozanecka 2010).

\section{Literatura}

Bożyk, P. (2008). Globalizacja a ekonomia (Globalization and economics). Ekonomista, 5, 680-681.

Gąsiorowski, P. (red.). (2012). Międzynarodowy Fundusz Walutowy w reakcji na światowy kryzys finansowy i gospodarczy (International Monetary Fund in response to the global financial and economic crisis), NBP, Warszawa, 18

Gliniak, P. (2016). Konsensus Waszyngtoński a doświadczenia Indonezji i Malezji w trakcie azjatyckiego kryzysu finansowego (The Washington consensus and the experience of Indonesia and Malaysia during the Asian financial crisis), Ekonomia XXI Wieku, 1(9), 65-79. 


\section{J. Kraciuk}

History of Lending Arrangements as of April 30, 2018. Pobrano z: http://www.imf.org/external/np/fin/tad/extarr2. aspx?memberkey $1=65 \&$ date 1 Key=2018-04-30, World Bank Group Finances,https://financesapp.worldbank. org/en/countries/ (stan na 02.09.2018).

Kaczmarczyk, Ł. Mika, A. (2004). Przegląd i znaczenie mierników zadłużenia zewnętrznego w kontekście krajowej i globalnej problematyki długu zewnętrznego. Analiza sytuacji zadłużeniowej Polski (Review and significance of external debt measures in the context of domestic and global external debt issues. Analysis of Poland's debt situation). Zeszyty Naukowe KGS SGH, 26, 72-94

Kozanecka, M. (2010). Niektóre konsekwencje konsensusu waszyngtońskiego w gospodarce i stosunkach społecznych państw Afryki Subsaharyjskiej (Some consequences of the Washington consensus in the economy and social relations of Sub-Saharan African countries). W: M. Lasoń, (red.) Między kryzysem a współpraca gospodarczą (Between crisis and economic cooperation), Krakowska Akademia im. Andrzeja Frycza Modrzewskiego, Kraków,147-148.

Latoszek, E, Proczek M. (2006). Organizacje międzynarodowe we współczesnym świecie (International organizations in the modern world). Dom Wydawniczy Elipsa, Warszawa, 183.

List of Least Developed Countries. Pobrano 28 września 2018 z: https://www.un.org/development/desa/dpad/wpcontent/uploads/sites/45/publication/ldc list.pdf.

Łoś-Nowak, T. (red.). (1998). Organizacje w stosunkach międzynarodowych. Istota - mechanizmy działania zasięg (Organizations in international relations. Essence - mechanisms of action - range). Wydawnictwo Uniwersytetu Wrocławskiego, Wrocław, 69-71.

Olszański, P. (2004). Rola Międzynarodowego Funduszu Walutowego i Banku Światowego we współczesnym świecie (The role of the International Monetary Fund and the World Bank in the modern world). W: P. Bożyk (red.). Egzemplifikacja międzynarodowych stosunków gospodarczych, (Exemplification of international economic relations). Oficyna Wydawnicza Wyższej Szkoły Handlu i Prawa im. Ryszarda Łazarskiego, Warszawa, 190-199.

Piasecki, R. (2008). Ekonomia rozwoju wobec problemów nędzy i nierówności społecznych na świecie (The economy of development against the problems of poverty and social inequality in the world). Annales. Etyka w Życiu Gospodarczym, 11(1), 225-232.

Soszyńska, E. (2013). Postwaszyngtoński konsensus, czyli: czy istnieją reguły budowy zdrowej gospodarki? (Postwashington consensus, or: are there rules for building a healthy economy?). Studia Ekonomiczne, 139, 112-121.

Stiglitz, J.E. (2004). The Post Washington Consensus, The Initiative for Policy Dialogue. Paper Presented at Conference: From the Washington Consensus towards a New Global Governance, Barcelona, September.

Stiglitz, J.E. (2007). Wizja sprawiedliwej globalizacji. Propozycje usprawnień (A vision of just globalization. Suggestions for improvements). PWN, Warszawa 35-36.

Stiglitz, J.E.(2012). Globalizacja, (Globalisation), PWN, Warszawa.

The World Bank. Data, https://data.worldbank.org/country (stan na: 02.09.2018).

Williamson, J. (1990). What Washington Means by Policy Reform. W: J. Williamson (red.). Latin American Adjustment: How Much has Happened?, Washington Institute for International Economics, Washington.

Williamson, J. (2000). What Should the World Bank Think about the Washington Consensus? World Bank Research Observer, 15(2), 251-264.

\section{Do cytowania / For citation:}

Kraciuk J. (2019). Wpływ międzynarodowych instytucji finansowych na sytuację gospodarczą krajów najsłabiej rozwiniętych. Problemy Rolnictwa Światowego, 19(3), 57-66;

DOI: $10.22630 /$ PRS.2019.19.3.46

Kraciuk J. (2019). Impact of International Financial Institutions on the Economic Situation of the Least Developed Countries (in Polish). Problems of World Agriculture, 19(3), 57-66;

DOI: 10.22630/PRS.2019.19.3.46 